\title{
Three new species of Mitracarpus Zucc. (Rubiaceae) from Brazil
}

\author{
Elsa L. Cabral, Sandra V. Sobrado \& Elnatan Bezerra de Souza
}

\author{
Abstract \\ CABRAL, E. L., S. V. SOBRADO \& E. B. SOUZA (2013). Three new species \\ of Mitracarpus Zucc. (Rubiaceae) from Brazil. Candollea 68: 139-146. In \\ English, English and French abstracts. \\ Three new species of Mitracarpus Zucc. (Rubiaceae), \\ Mitracarpus carajasensis E. L. Cabral, Sobrado \& E. B. Souza, \\ Mitracarpus federalensis E. L. Cabral, Sobrado \& E. B. Souza \\ and Mitracarpus fernandesii E. L. Cabral, Sobrado \& E. B. \\ Souza, from Brazil, are described, illustrated and compared to \\ related taxa.
}

\section{Key-words}

RUBIACEAE - Mitracarpus - Brazil - Taxonomy

\section{Résumé}

CABRAL, E. L., S. V. SOBRADO \& E. B. SOUZA (2013). Trois nouvelles espèces de Mitracarpus Zucc. (Rubiaceae) du Brésil. Candollea 68: 139-146. En anglais, résumés anglais et français.

Trois nouvelles espèces de Mitracarpus Zucc. (Rubiaceae), Mitracarpus carajasensis E. L. Cabral, Sobrado \& E. B. Souza, Mitracarpus federalensis E. L. Cabral, Sobrado \& E. B. Souza et Mitracarpus fernandesii E. L. Cabral, Sobrado \& E. B. Souza, décrites du Brésil, sont illustrées et comparées aux taxons proches.

Addresses of the authors: ELC, SVS: Instituto de Botánica del Nordeste, av. Sargento Cabral 2131, C.C. 109, C.P. 3400 / Universidad Nacional del Nordeste, Facultad de Ciencias Exactas y Naturales y Agrimensura, Corrientes, Argentina. Email (ELC): ecabral@agr.unne.edu.ar 


\section{Introduction}

As part of the study of American representatives of the tribe Spermacoceae (Rubiaceae), recent collections from Pará, Distrito Federal and Ceará States, Brazil, were analyzed. Three species of the genus Mitracarpus Zucc. not previously described were discovered. According to molecular studies (DESSEIN, 2003), this genus is monophyletic, characterized by a 4-merous calyx, with two large and two small lobes, transversally dehiscent capsular fruits and seeds with the ventral face depressed (SouzA \& al., 2010). It is represented by nearly 50 species in tropical and subtropical regions of the American continent, from southern United States to central Argentina, Mexico, the Caribbean and Brazil being the main centers of diversity (SouzA, 2008). In Brazil, 25 species, 15 of which are endemic, have been recognized. In this work, three new taxa are described and illustrated. The seed morphology of the three species was analyzed using a Scanning Electron Microscope.

Mitracarpus carajasensis E. L. Cabral, Sobrado \& E. B. Souza, spec. nova (Fig. 1, 2A-B).

Typus: Brazil. Pará: Canaã dos Carajás, $6^{\circ} 23^{\prime} 1$ 'S 50²3'10”'W, 753 m, 16.III.2009, fl fr, V. T. Giorni, P. L. Viana, L. M. Versieux, L. M. Garcia, L. V. C. Silva \& D. S. Silva 196 (holo-: BHCB!; iso-: CTES!).

Mitracarpo parvulo affinis, sed ab eo habito erecto (vs caespitoso), caulibus glabris (vs pubescentibus), foliis 20$29 \mathrm{~mm}$ longis et 1-2 mm latis (vs foliis 7-15 mm longis et 1-4 mm latis), setis stipularibus 4-5 (vs 5-7), 2(-4) bracteis involucralibus foliaceis glomerulis inflorescentiae quatruplo longioribus (vs 4 bracteis inequalibus in glomerulis terminalibus), seminibus dorso lineis 2 cruciformiter depressis (vs sine depressione dorsali), differt.

Simple or sparsely branched, erect herb, $15-25 \mathrm{~cm}$ tall. Stems subcylindrical to quadrangular, glabrous, internodes $2.5-5 \mathrm{~cm}$ long. Leaves sessile, leaf-blades 20-29 × 1-2 mm, linear, glabrous, apex attenuate, base acute, margins revolute, scaberulous, secondary veins obscure. Stipules 1-1.5 mm long, ribs and bristles pilose basally violet, bristles $4-5$, ca. 1-1.5 mm, linear, glabrous. Inflorescence a terminal glomerule, 5-6 $\mathrm{mm}$ wide, subtended by 2(-4) foliaceous bracts, 4 times longer than the glomerule, 1-2 axillary glomerules also present. Flowers with hypanthium 0.5$1 \mathrm{~mm}$ long, glabrous, calyx 4-merous, 2 large lobes, $1.3-2 \mathrm{~mm}$ long, subtriangular, exceeding the corolla tube, greenish, margins ciliate; 2 small lobes, ca. $0.5-1 \mathrm{~mm}$ long, hyaline; corolla white, 2-3 mm long, infundibuliform, tube $1.3 \mathrm{~mm}$ long, inside with moniliform hairs around the tube's base, papillose inside and outside. Stamens subsessile, filaments 0.1-0.2 mm long, anthers $0.5 \mathrm{~mm}$. Style 1.5-2 mm long, style-arms 0.1-0.3 mm long, papillose. Capsule $1 \times 1 \mathrm{~mm}$, glabrous. Seeds obovoid, 0.6$1 \times 0.6 \mathrm{~mm}$, light brown; the ventral face with an X-shaped groove covered with whitish granular excrescences and the dorsal face with central cruciform depression and angular depressions caused by the extensions of the ventral groove, testa reticulate-foveate with irregularly outlined cells (Fig. 3A-D).

Distribution and habitat. - Brazil, in Pará State, in the microregion of Canaã dos Carajás and Parauapebas. It grows in rocky field on "canga". The canga vegetation is characterized by the patches of saxicolous scrubby vegetation on the iron outcrops, usually on mountain summits (SECCO \& Mesquita, 1983).

Notes. - Mitracarpus carajasensis is related to M. parvulus K. Schum., the corolla tube being shorter than the lobes of the calyx. Both have opposite leaves and lack brachyblasts. However, the latter is a cespitose herb, branched from the base, with marked pubescence and seeds without depressions on the dorsal faces.

Paratypi. - BrazIL. Pará: Canaã dos Carajás, 6²1'30.69'S 50²3'58.91'”, 700 m, 18.V.2010, L. C. V. Silva \& al. 880 (BHCB, CTES); 6²0'34.32”'S 50²5'24.04”'W, 700 m, 19.V.2010, L. C. V. Silva \& al. 889 (BHCB, CTES); 6²3'48.94'S 50²2'21.84”W, 728 m, 22.III.2012, A. J. Arruda \& al. 773 (BHCB, CTES); 6¹7’2.38”S 50²0'13.13”'W, 580 m, 22.III.2012, A. J. Arruda \& al. 779 (BHCB, CTES); 6²2'32.10”'S 50²2'58”'W, 715 m, 22.III.2012, P. B. Mayer \& al. 1163 (BHCB, CTES); Serra da Bocaina, 6¹9'35.39”'S 4958'5.53”W, 697 m, 20.IV.2012, A. J. Arruda \& al. 960 (BHCB, CTES); Parauapebas, 6 ${ }^{\circ} 11$ '1.63"S 50॰7'47.31'W, $701 \mathrm{~m}$, 23.III.2012, P. B. Mayer \& al. 1166 (BHCB, CTES); 64'23.74”S 50¹1'35.08”'W, 554 m, 24.III.2012, P. B. Mayer \& al. 1195 (BHCB, CTES); 69'13.18”S 50¹0'20.79”'W, 693 m, 25.III.2012, P. B. Mayer \& al. 1229 (BHCB, CTES).

Mitracarpus federalensis E. L. Cabral, Sobrado \& E. B. Souza, spec. nova (Fig. 4).

Typus: Brasil. Distrito Federal: APA Gama e Cabeça de Veado, ARIE do Córrego do Cedro, R. A. do Núcleo Bandeirante, 15 54 $54^{\prime} 00.5^{\prime}$ 'S 47 $57^{\prime} 16.0^{\prime \prime} \mathrm{W}, 23 . \mathrm{IV} .2003$, $\mathrm{fl} \mathrm{fr}$, M. L. Fonseca \& D. Alvarenga 4582 (holo-: IBGE; iso-: CTES!).

Mitracarpo eitenii affinis, sed ab eo habitu maiore 50$60 \mathrm{~cm}$ alto (vs $15-50 \mathrm{~cm})$, glomerulis floralibus terminalibus et axillaribus minoribus, $8-12 \mathrm{~mm}$ in diametro, aequalibus (vs 13-20 mm diam., et terminalibus majoribus quam axillaribus), 2(-4) bracteis involucralibus (vs 2-8), lobis calycis longioribus 2-2.5 mm (vs 3-4 mm) longis, tubo corollae 4-4.6 mm longo, in tertio superiore pilis hyalinis instructo, lobis corollinis apice pilosis extus pilis purpureis confertis pilosi intus papillosi (vs 3-4 mm longis, tubo puberulo, lobis tantum dense puberulis), seminibus $0.7 \times$ $0.5 \mathrm{~mm}$, reticulatis (vs $0,8 \times 0,6 \mathrm{~mm}$, laevibus), differt.

Branched, erect or scandent herb, 50-60 cm tall, lateral branches opposite. Stems quadrangular, 1-2 mm broad, densely pubescent on young branches and near the glomerules, internodes 7-13 cm long. Leaves 22-33 $\times 5-8 \mathrm{~mm}$, lanceolate, chartaceous, apex acuminate, margins revolute, scaberulous, both 


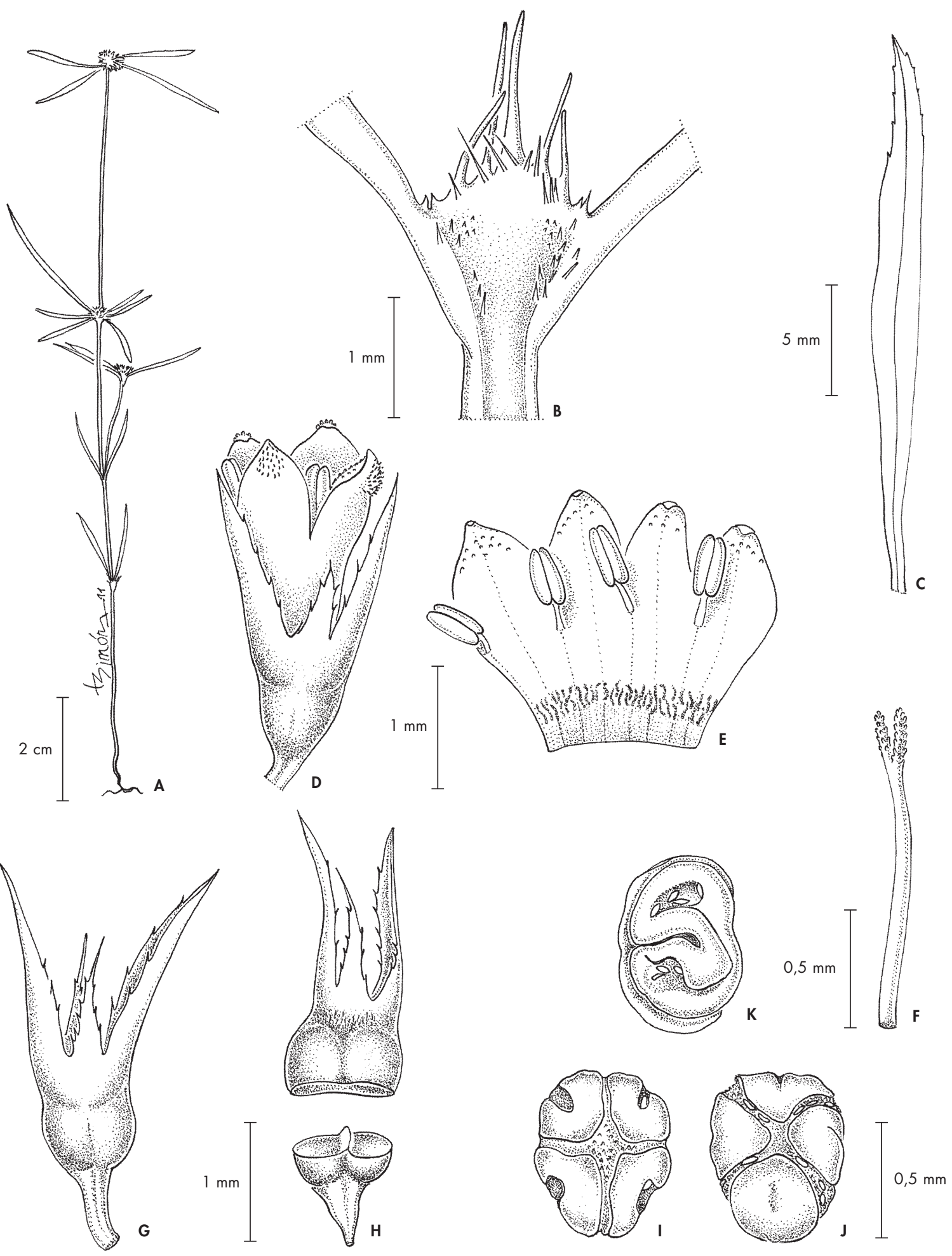

Fig. 1. - Mitracarpus carajasensis E. L. Cabral, Sobrado \& E. B. Souza. A. Habit; B. Stipular sheath; C. Leaf-blade; D. Flower ; E. Corolla; F. Style and stigma; G. Calyx; H. Dehiscent fruit; I-K. Seed; I. Dorsal view; J. Ventral view; K. Lateral view.

[Giorni \& al. 196, BHCB] [Drawing: L. Simón] 

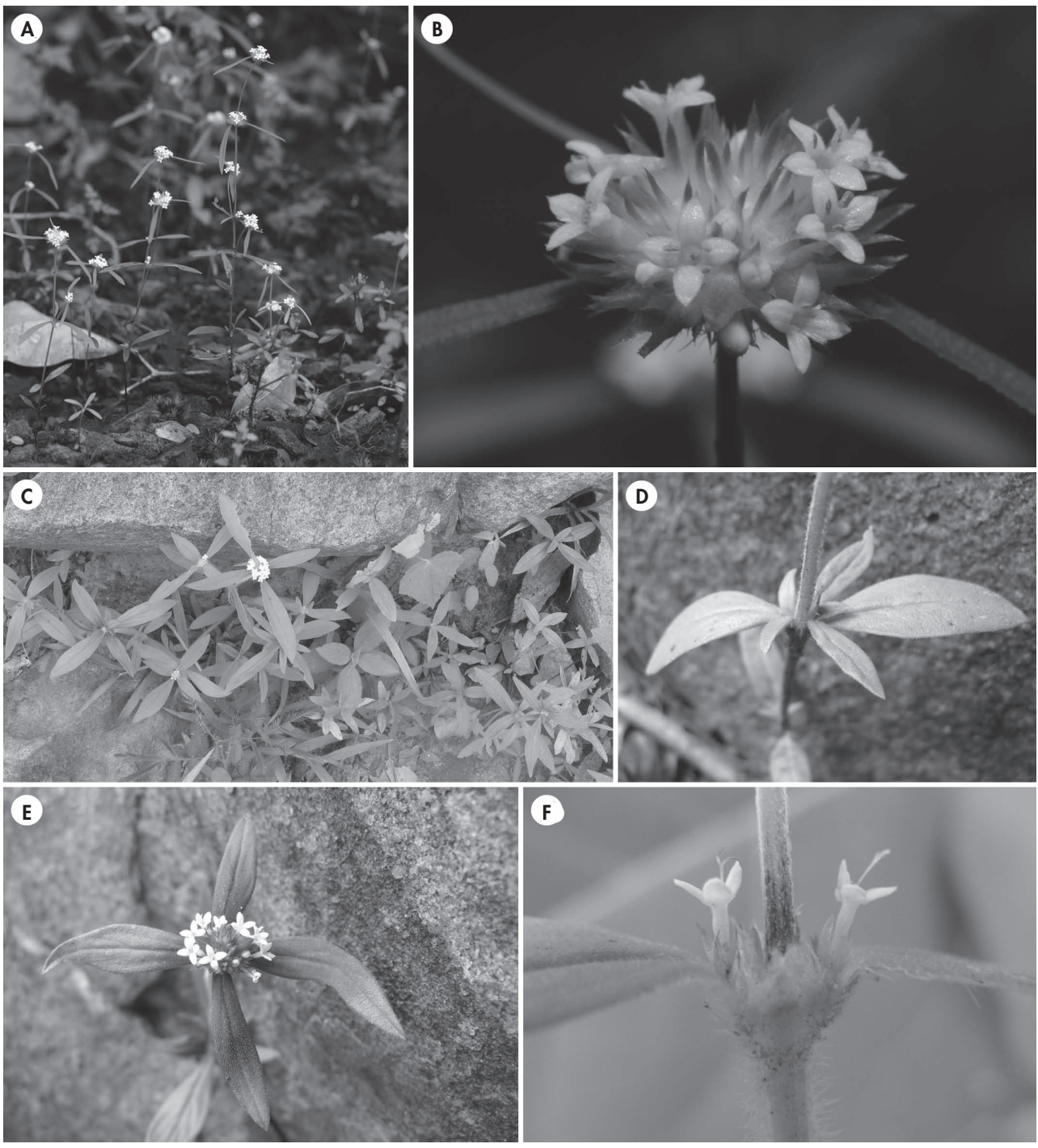

Fig. 2. - Mitracarpus carajasensis E. L. Cabral, Sobrado \& E. B. Souza: A. Habit; B. Terminal glomerule. Mitracarpus fernandesii E. L. Cabral, Sobrado \& E. B. Souza: C. Habit; D. Pseudoverticillate leaves; E. Terminal glomerule, 1 pair of bracts located between the flowers are shown; F. Flowers of the axillary glomerule.

[Photos: A-B: P. L. Viana; C-F: E. B. Souza]

surfaces puberulous, main nerves pilose on the lower surface, secondary nerves obscure; stipular sheath 2-3 mm long, subtriangular, covered with hyaline hairs, bristles 5-6, 1.5-3(-3.5) $\mathrm{mm}$, linear, glabrous. Inflorescence a terminal glomerule, 8$12 \mathrm{~mm}$ wide, globose, multi-flowered, 2-3 axillary glomerules also present; involucral bracts 2(-4), foliaceous, $15-20 \times$ 4-5 $\mathrm{mm}$, twice the length of the glomerule, violet at the base, puberulous on both faces. Flowers pedicellate, pedicels 0.7-1 mm long, hyphantium 1-2 mm long, obconical, puberulous; calyx 4-merous, 2 large lobes, 2-2.5 mm long, half as long as the corolla tube, carinate, margins ciliate, greenish, the base brown; 2 small lobes, 1-2 mm long, triangular, ciliate; corolla white, 5.5-6 mm long, infundibuliform, tube 4-4.6 mm long, the exterior with trichomes in the upper part, the interior with moniliform hairs in the lower third, lobes 1-1.5 mm long, the outer surface with a tuft of purple hairs, inner surface papillose. Stamens sessile, anthers ca. $1 \mathrm{~mm}$. Style $1.5(-5.5) \mathrm{mm}$ long, style-arms 0.6-1.5 mm long. Capsule $1.5 \times 2 \mathrm{~mm}$, globose, glabrescent. Seeds obovoid, $0.7 \times 0.5 \mathrm{~mm}$, brown, the ventral face with an $\mathrm{X}$-shaped groove, which is densely covered with granular excrescences, the dorsal face lacking both a central depression and angular depressions caused by extensions of the ventral groove, the testa irregulary reticulatepapillate (Fig. 3E-I). 

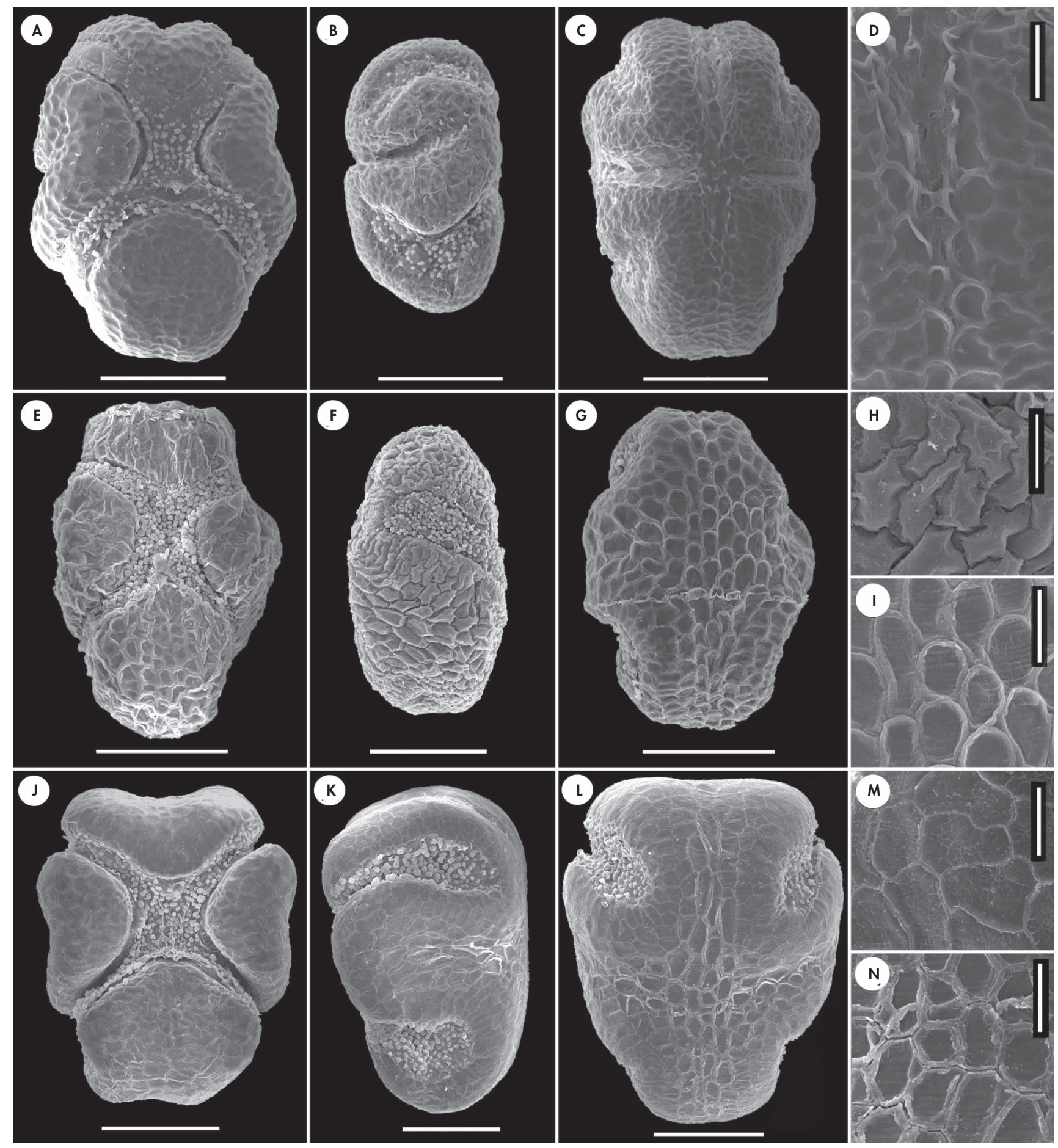

Fig. 3. - Seed morphology (SEM-graphs). Mitracarpus carajasensis E. L. Cabral, Sobrado \& E. B. Souza: A. Ventral view; B. Lateral view, notice the extensions of the ventral groove and the dorsal face depression; C. Dorsal view; D. Detail of reticulate-foveate testa. Mitracarpus federalensis E. L. Cabral, Sobrado \& E. B. Souza: E. Ventral view; F. Lateral view, notice the extensions of the ventral groove; G. Dorsal view; H. Detail of testa of the lateral face, showing the hydrated papillas; I. Detail of testa of the dorsal face, showing the dehydrated papillas. Mitracarpus fernandesii E. L. Cabral, Sobrado \& E. B. Souza: J. Ventral view; K. Lateral view, notice the extensions of ventral groove and dorsal depression; L. Dorsal view; M. Detail of reticulate-areolate testa of the dorsal angle; N. Detail of reticulate testa of the dorsal depression [Scale bars: A-C, E-G, J-L: $0.25 \mathrm{~mm}$; D, H-I, M-N: $50 \mu \mathrm{m}]$.

[A-D: Giorni \& al. 196, BHCB; E-I: Fonseca \& Alvarenga 4582, IBGE; J-N: Souza \& al. 1737, HUVA] 


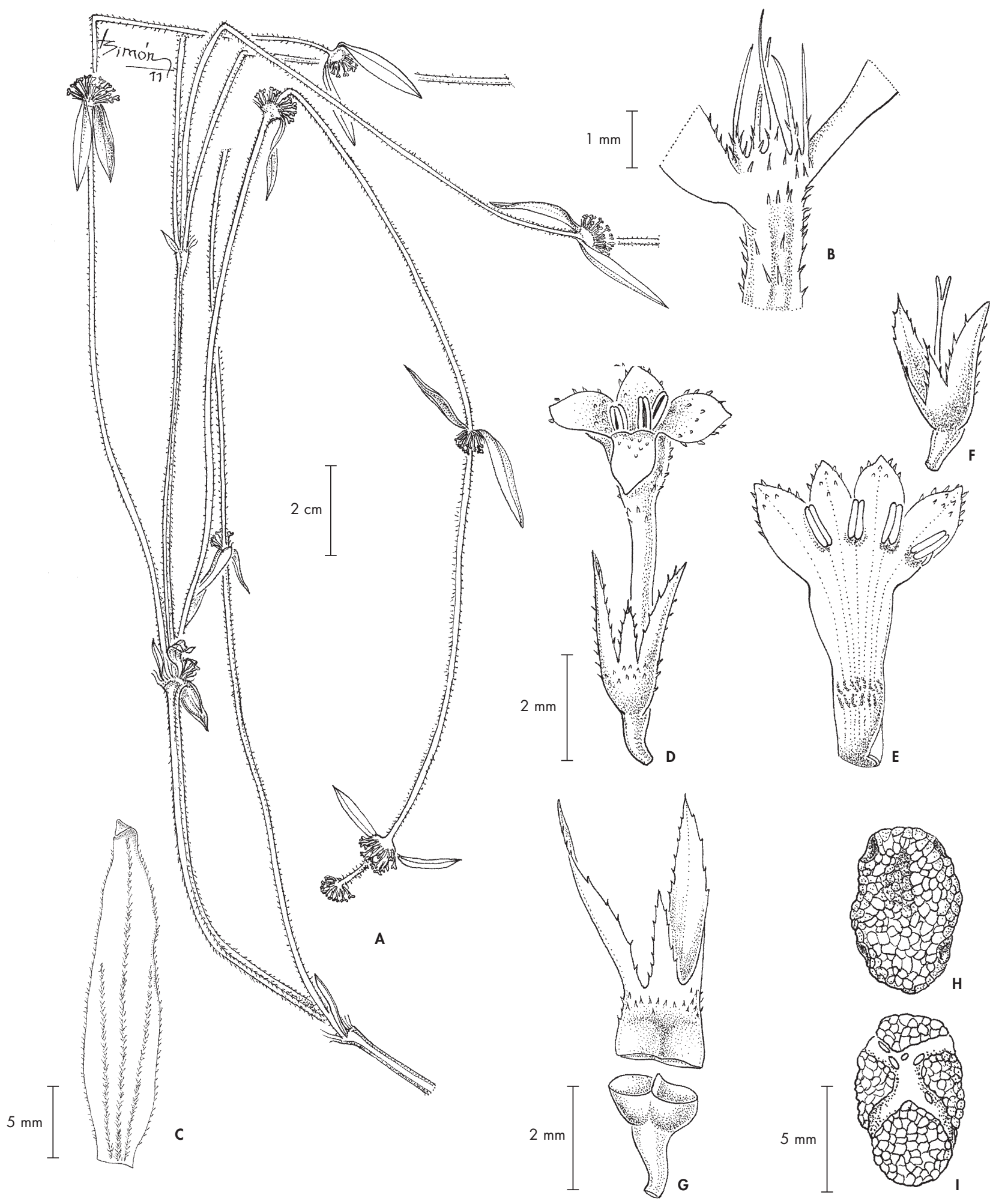

Fig. 4. - Mitracarpus federalensis E. L. Cabral, Sobrado \& E. B. Souza. A. Habit; B. Stipular sheath; C. Leaf-blade; D. Flower; E. Corolla; F. Hypanthium, calyx, style and stigma; G. Dehiscent fruit; H-I. Seed; H. Dorsal view; I. Ventral view.

[A: Fonseca \& Alvarenga 4620,CTES; B-I: Fonseca \& Alvarenga 4582, IBGE] [Drawing: L. Simón] 
Distribution and habitat. - Brazil, Distrito Federal. This species grows in an area with flat relief, red laterite soil and a small strip of degraded cerrado lying between the highway and railway at an altitude of $1030 \mathrm{~m}$.

Notes. - Mitracarpus federalensis is characterized by the ventral face of the seeds having an X-shaped groove and the dorsal face lacking a depression. Given that the species does not possess seeds with a cruciform dorsal depression (like as M. baturitensis Sucre or M. frigidus (Roem. \& Schult.) K. Schum.) nor semicircular dorsal depressions (like as M. longicalyx E. B. Souza \& M. F. Sales), it is clearly related to M. eitenii E. B. Souza \& E. L. Cabral. However, it differs from that species by its habit, the size and development of the inflorescence and the size and indumentum of the flowers and seed surface.

Paratypi. - BrazIL. Distrito Federal: APA Gama e Cabeça de Veado, 1545'38.3"'S 47057'26.3"W, 23.IV.2003, M. L. Fonseca \&

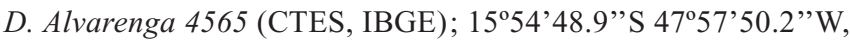
29.IV.2003, M. L. Fonseca \& D. Alvarenga 4620 (CTES, IBGE).

Mitracarpus fernandesii E. L. Cabral, Sobrado \& E. B. Souza, spec. nova (Fig. 5, 2C-F).

Typus: BraziL. Ceará: Planalto da Ibiapaba, Mun. Pacujá, Distrito Bom Gosto, Serrinha, 0403'03's 4042'25'W, 190 m, 26.VIII.2009 (fl, fr), E. B. Souza, M. F. Mata, I. M. Andrade, J. W. A. Nogueira \& M. O. M. Mesquita 1737 (holo-: HUVA!; iso-: CTES!).

Mitracarpo longicalyci affinis, se dab eo foliis pseudoverticillatis (vs oppositis), glomerulis terminalibus $1-1.5 \mathrm{~cm}$ in diam. et axillaribus $0.5-1 \mathrm{~cm}$ in diam. (vs 9-12 $\mathrm{mm}$ et 6$9 \mathrm{~cm}$ ), corolla 5-6.5 mm longa et tubo 4.5-5.2 $\mathrm{mm}$ longo (vs 3-5 $\mathrm{mm}$ et 2-3.5 $\mathrm{mm}$ longo), lobis longioribus calycis dimidio tubo corollae aequalibus (vs ultra medium tubi corollae), seminibus dorso sine depressione semicirculari (vs cum depressione semicirculari), differt.

Erect, branched herb, (5-)10-37 cm tall, lateral branches opposite, stems quadrangular, pilose, 1-3 mm broad, internodes 1-9 cm long. Leaves pseudoverticillate, leaf-blades 9-40 $\times 3$ $11 \mathrm{~mm}$, lanceolate, chartaceous, base attenuate into a pseudopetiole, secondary veins 3-4 pairs, upper surface puberulous, lower surface pilose on the nerves, margins scaberulous; stipular sheath pilose, 1.5-3 mm long, bristles 5-7, 1-3 mm, linear, glabrous. Inflorescence of terminal and 1-3 axillary glomerules, globose, many-flowered, the terminal glomerule $1-1.5 \mathrm{~cm}$ wide, the axillary $0.5-1 \mathrm{~cm}$ wide; involucral bracts $4-6$, unequal, puberulous, violet or purple at the middle or lower third, 2 pairs generally longer than the glomerule (larger 20-46 × 4-11 mm; smaller 6$15 \times 1-3 \mathrm{~mm}$ ), but sometimes 1 pair of bracts shorter than the glomerule, this located between the flowers. Flowers pedicellate, pedicel $0.7-1 \mathrm{~mm}$ long, hyphantium 1-1.5 mm long, turbinate, glabrous; calyx 4-merous, 2 large lobes, 2-2.3 mm long, up to half the length of the corolla tube, margins scabrid, lanceolate, greenish, 2 small lobes, 1.3-1.5 mm long, triangular, scabrid. Corolla white, $5-6.5 \mathrm{~mm}$ long, infundibuliform, inside with moniliform hairs in the lower third of the tube, outside glabrous; tube 4.5-5.2 mm long; lobes 1-1.5 mm long, glabrous. Stamens subsessile, anthers $0.8 \mathrm{~mm}$. Style $4-5 \mathrm{~mm}$ long, stylearms 0.4-1 mm long, papillose. Capsule $1 \times 1 \mathrm{~mm}$, obovoid, glabrous. Seeds obovoid, 0.7-1 $\times$ 0.5-0.7 mm, brown, ventral face with an X-shaped groove, densely covered with granular excrescences, dorsal face with a weak central cruciform depression and angular depressions caused by the extensions of the ventral groove, testa reticulate in the depression and reticulateareolate in the rest of the surface (Fig. 3J-N).

Distribution and habitat. - Brazil, Ceará, growing in Caatinga, in transition to Cerrado on sandy soils between rocks.

Etymology. - Mitracarpus fernandesii is dedicated to the eminent botanist Afrânio Fernandes, who has greatly contributed to our knowledge of the Ceará Flora.

Paratypi. - Brazil. Ceará: Mun. Pacujá, Distrito Bom Gosto, Serrinha, 04 03'10"S 4042'12”W, 220 m, 26.VII.2009, E. B. Souza \& al. 1740 (CTES, HUVA); Mun. Pacujá, Distrito Bom Gosto, Serrinha, 04 03'10"S 4042'12'W, 220 m, 16.III.2011, E. B. Souza \& al. 2066 (HUVA); Mun. Pacujá, Distrito Bom Gosto, Serrinha, 0403'10"S 4042'12”W, 220 m, 16.III.2011, E. B. Souza \& al. 2069 (HUVA).

\section{Acknowledgements}

We are grateful to the curator of $\mathrm{BHCB}$ and the curator of IBGE for sending specimens and to Laura Simon to enable the preparation of the illustrations. We also thank Dr A. L. Borhidi for the help on Latin diagnosis and Dr John Wood for assistance with the English language.

\section{References}

Dessein, S. (2003). Systematic studies in the Spermacoceae (Rubiaceae). $\mathrm{PhD}$ thesis. Katholieke Universiteit Leuven.

Secco, R. S. \& A. I. Mesquita (1983). Notas sobre a vegetação de canga na Serra Norte I. Bol. Mus. Paraense "Emilio Goeldi", N. S., Bot. 59: 1-13.

Souza, E. B. (2008). Estudos Sistemáticos em Mitracarpus (Rubiaceae - Spermacoceae) com ênfase em espécies brasileras. Tese de Doutorado. Universidade Estadual de Feira de Santana. Departamento de Ciências Biológicas. Programa de Pós-Graduação em Botânica. Feira de Santana - Bahia, Brasil.

Souza, E. B., E. L. CABral \& D. C. ZAppi (2010). Revisão de Mitracarpus (Rubiaceae - Spermacoceae) para o Brasil. Rodriguésia 61 : 319-352. 


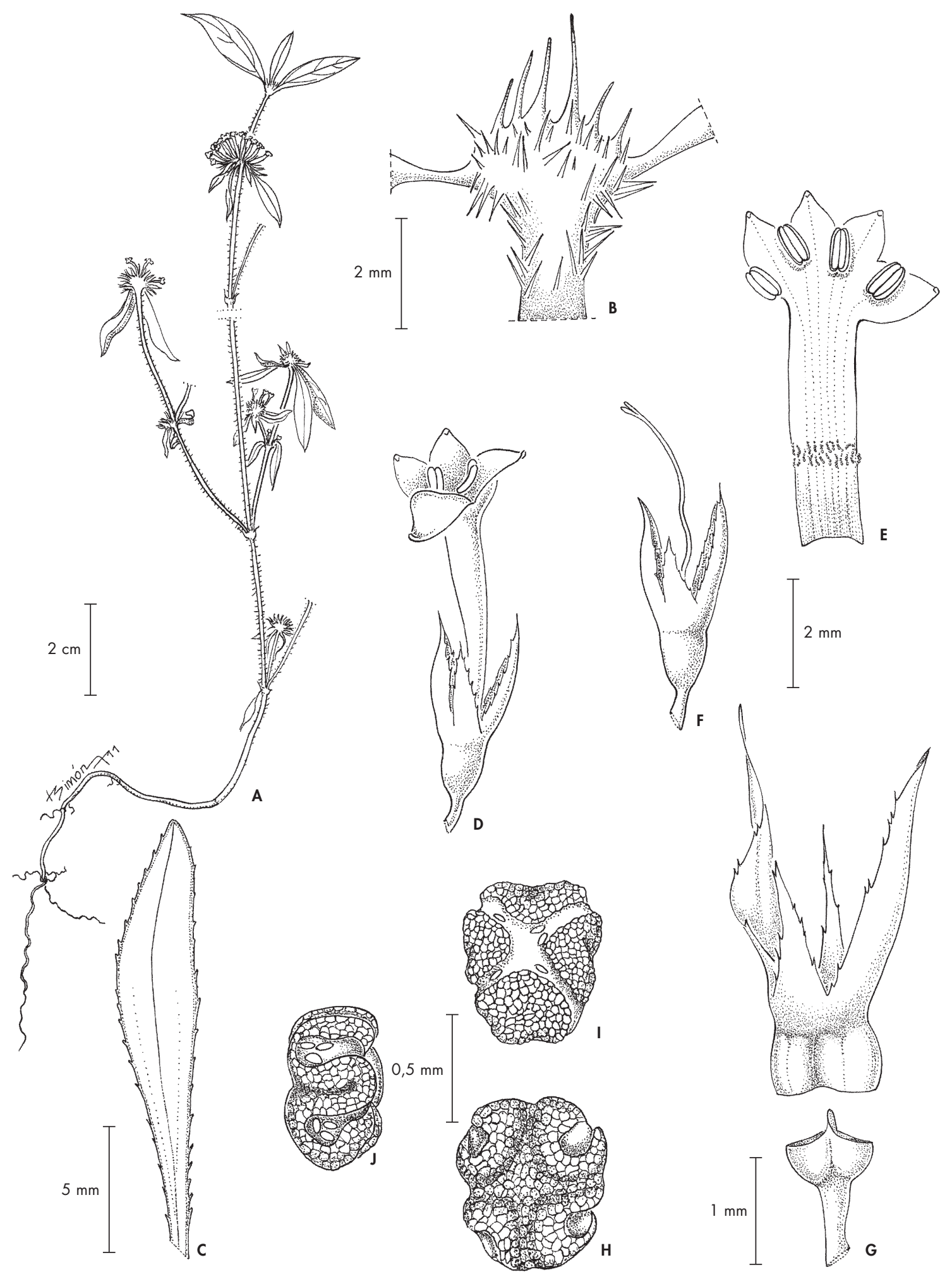

Fig. 5. - Mitracarpus fernandesii E. L. Cabral, Sobrado \& E. B. Souza. A. Habit; B. Stipular sheath; C. Leaf-blade; D. Flower; E. Corolla; F. Hypanthium, style and stigma; G. Dehiscent fruit; H-J. Seed; H. Dorsal view; I. Ventral view; J. Lateral view.

[Souza \& al. 1737, HUVA] [Drawing: L. Simón] 